\title{
Design, Synthesis and Cytotoxicity Study of Primary Amides as Histone Deacetylase Inhibitors
}

\section{Duraid Al-Amily ${ }^{* 1}$ and Mohammed H. Mohammed*}

*Department of Pharmaceutical Chemistry, College of Pharmacy, University of Baghdad, Baghdad, Iraq.

\section{Abstract}

Primary amide derivatives as histone deacetylase inhibitors (HDACIs) are very rare. This paper describes the synthesis of the primary amide derivatives adipic monoanilide amide and pimelic monoanilide amide (compounds 6 and 7) that have the requirements to be histone deacetylase inhibitors of the zinc-binding type. Both of them exhibited good cytotoxicity against the tested cancer cell lines with much lower cytotoxicity against normal cell line.

Keywords: Primary amides, HDACIs, Adipic monoanilide amide, Pimelic monoanilide amide

$$
\begin{aligned}
& \text { تصميم، تخليق، و دراسة السمية الخلوية للأمايدات الاولية كمثبطات لأنزيم الهيستون دي اسيتيليز }
\end{aligned}
$$

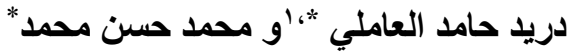

$$
\begin{aligned}
& \text { فرع الكيمياء الصيدلانية، كلية الصيدلة، جامعة بغداد، بغداد، العراق. } \\
& \text { الخلاصة }
\end{aligned}
$$

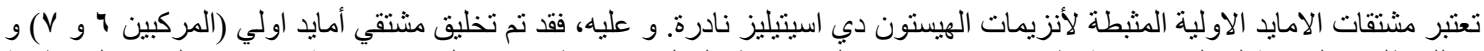

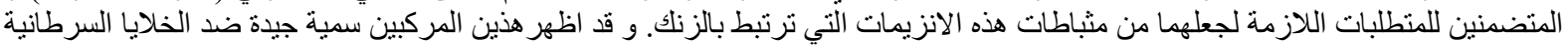

$$
\begin{aligned}
& \text { و ضعيفة ضند الخلايا الطبيعية. }
\end{aligned}
$$

Introduction

Histone deacetylases (HDACs) are a group of enzymes responsible for the deacetylation of the $\varepsilon$-amino groups of lysine residues at the $\mathrm{N}$-termini of histones ${ }^{(1)}$, the core proteins that serve to compact DNA into nucleosomes which comprise chromatins (2). The deacetylation process encourages the compaction of nucleosomes and repression of gene transcription ${ }^{(3)}$. Many reports demonstrate that HDACs are overexpressed in several types of cancer ${ }^{(1,4)}$. Therefore, they are considered as valuable targets for cancer treatment (5).

Eighteen isoforms of HDACs have been identified in mammalian tissues. They fall into four major classes (I-IV). Class I includes HDAC1, 2, 3, and 8 while class II includes isoforms 4-7, 9 and 10 .
Isoform 11 represents class IV. These three classes have a zinc-dependent catalytic site. The rest seven isoforms depend on the cofactor nicotine adenine dinucleotide rather than zinc for their catalytic activity and comprise class III ${ }^{(6)}$.

The zinc-dependent classes are highly investigated and subjected to inhibition studies as an approach for cancer treatment ${ }^{(7)}$. A classical and popular example is HDAC2 since its crystallographic structure is well resolved (8). Previous studies on the binding site revealed that it is shaped as an internal tubular (tunnel) cavity having a length of $11 \AA$. At the bottom of this cavity lies a zinc ion followed by a $14 \AA$ foot-like pocket ${ }^{(9)}$ (Figure 1). Lysine residues of histone fit into the tunnel so that they could be deacetylated ${ }^{(3)}$.
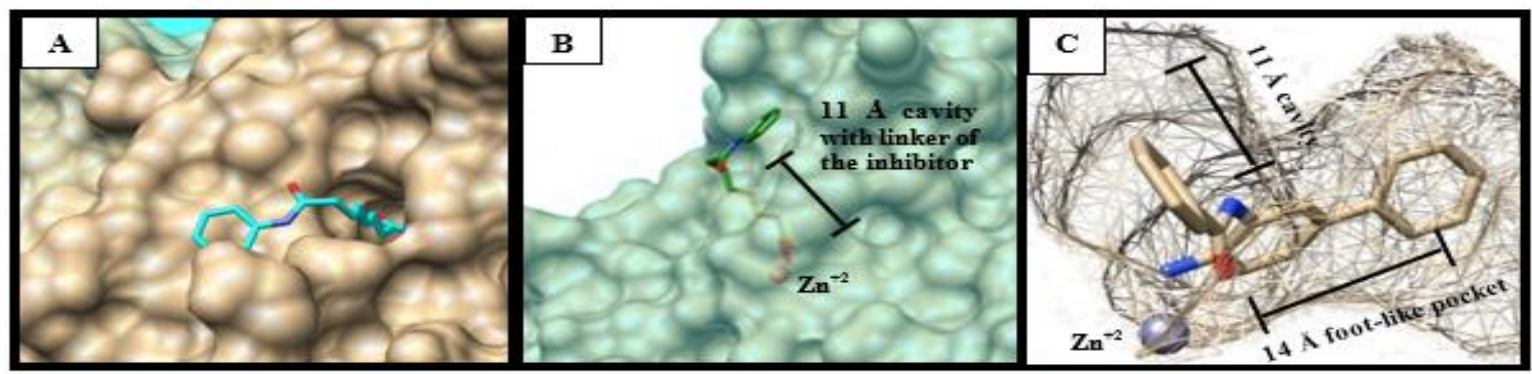

Figure 1 .The binding site of HDAC2. (A): The opening of the tunnel cavity is shown in which the linker of the inhibitor (cyan) is lying. (B): A side view of the binding site with $30 \%$ transparency of the surface to make the whole length of the tunnel $(11 \AA)$ visible together with the linker of the inhibitor (forest green). Zinc ion is visible at the deepest end of the tunnel. (C): Mesh surface of the binding site showing the inhibitor inside the $14 \AA$ foot-like pocket.

${ }^{1}$ Corresponding author E-mail : colrelated@copharm.uobaghdad.edu.iq

Received: 31/ 5 /2019

Accepted: 21/8 / 2019

Iraqi Journal of Pharmaceutical Sciences 
Accordingly, the design of inhibitors for zinc-dependent HDACs should have a zinc binding group (ZBG) to bind to the zinc ion, a linker of 4-6 carbon atoms length to fit into the cavity, and a hydrophobic cap to recognize and interact with the outer surface ${ }^{(1)}$. These are best illustrated by the classical inhibitor suberoylanilide hydroxamic acid 1 (SAHA, vorinostat) ${ }^{(10)}$.Other known synthetic inhibitors with ZBG other than hydroxamic acid derivatives include entinostat 2 (MS-275), a benzamide, and valproic acid $\mathbf{3}^{(5)}$ (Figure 2). Among other rare synthetic ZBG are the secondary amide derivative $\mathbf{4}^{(11,12)}$ and the only primary amide 5 mentioned in the literature that showed an $\mathrm{IC}_{50}$ against HDAC1 in a nanomolar concentration ${ }^{(13)}$.

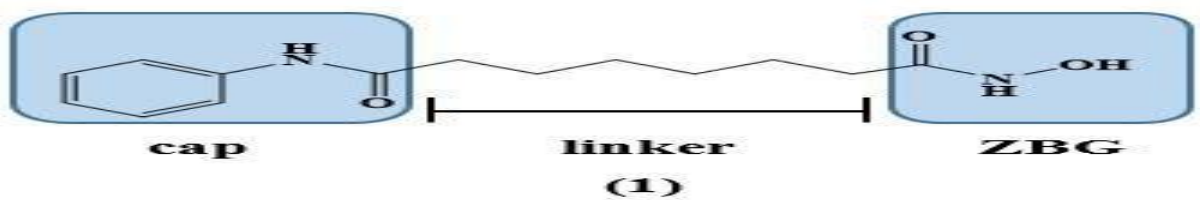<smiles>Nc1ccccc1NC(=O)c1ccc(CNC(=O)OCc2cccnc2)cc1</smiles><smiles>CCCC(CCC)C(=O)O</smiles>

(3)

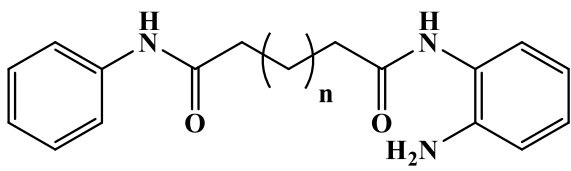

(4)

$\mathrm{n}=2,3$, and 4<smiles>COc1ccc2[nH]c(C)c(CC(=O)N[C@@H](CCCCCC(N)=O)c3ncc(-c4ccc5ccccc5c4)[nH]3)c2c1</smiles>

Figure2. Examples of HDAIs with different ZBGs

Here, we wish to describe the synthesis of the small and simple primary amide molecules $\mathbf{6}$ and $\mathbf{7}$ that fulfill the three requirements for zinc-dependent HDAC inhibitors.

$$
\begin{aligned}
& \text { (6) } n=2 \\
& \text { (7) } n=3
\end{aligned}
$$

Besides, we'll mention the results of the in vitro cytotoxicity assay for these compounds against HRT-18 cell line (human colon adenocarcinoma) and $\mathrm{HC}-04$ cell line (mouse hepatic carcinoma).

\section{Materials and Methods}

Reagents and solvents were used for chemical synthesis as obtained from the supplier (Sigma-Aldrich, Fluka, Romil, GCC Diagnostics, ReagentWorld, and Thomas-Baker). Melting points were measured using the Stuart SMP3 melting point apparatus (UK) and are uncorrected. Thin-layer chromatography was achieved using $0.2 \mathrm{~mm}$ precoated TLC-sheets Alugram ${ }^{\circledR}$ Xtra SIL G/UV254 (Macherey-Nagel, Germany) and the visualization was under a $254 \mathrm{~nm}$ UV lamp. FT-IR spectroscopy was done using Shimadzu IRAffinity-1 Spectrometer (Shimadzu, Japan) and Specac ${ }^{\circledR}$ Quest ATR- diamond type (UK) at the University of Baghdad-College of Pharmacy. ${ }^{1} \mathrm{H}-\mathrm{NMR}$ and ${ }^{13} \mathrm{C}$ NMR analysis was performed at $400 \mathrm{MHz}$ and 100 $\mathrm{MHz}$ respectively ( $d_{6}$ - DMSO as the solvent) using 
The Bruker Avance III, $400 \mathrm{MHz}$ spectrometer (USA) at Sophisticated Test and Instrumentation Centre (Cochin University of Science and Technology-India), with the chemical shifts $(\delta)$ expressed in parts per million.

Figures illustrating the binding site of HDACs and the binding of the ligand were captured using UCSF Chimera (14) and the PDB (www.rcsb.org) ${ }^{(15)}$ files with IDs $4 \mathrm{LXZ}{ }^{(8)}$ and $3 \mathrm{MAX}^{(16)}$.

Cytotoxicity assay was performed at the iRAQ Biotech laboratories using trypsin/EDTA, RPMI 1640, fetal bovine serum (Capricorn, Germany); 3- ( 4 , 5 - dimethyl - 2 - thiazolyl) -2,5diphenyl-2H-tetrazolium bromide (MTT stain- BioWorld, USA); dimethyl sulfoxide (DMSOSantacruz Biotechnology, USA); $\mathrm{CO}_{2}$ incubator and laminar flow hood (Cypress Diagnostics, Belgium); microtiter reader (Gennex lab., India); cell culture plates (Santa Cruz Biotechnology, USA).

\section{Chemical synthesis (scheme 1) General synthesis of adipic and pimelic anhydrides (6b and 7b)}

Adipic acid (6a) or pimelic acid (7a) (27.4 mmol of each) was suspended in acetic anhydride ( 3 $\mathrm{mL} / \mathrm{g}$ ) and refluxed for 1 hour. The solvent was then evaporated under reduced pressure to obtain a semisolid mixture of $\mathbf{6 b}$ and $\mathbf{6 c}$, or $\mathbf{7 b}$ and $\mathbf{7 c}$, which was used as such in the next step. FT-IR (ATR; v, $\left.\mathrm{cm}^{-1}\right)$ : 1801, 1739 for $\mathbf{6 b}$ and 1813, 1743 for $\mathbf{7 b}$ (sym. and asym. $\mathrm{C}=\mathrm{O}$ respectively).

\section{General synthesis of monosodium adipic monoanilide and monosodium pimelic monoanilide (6d and $7 d$ )}

The obtained mixture of compounds $\mathbf{6 b}$ and $\mathbf{6 c}$, or $\mathbf{7 b}$ and $\mathbf{7 c}$ was dissolved in $10 \mathrm{~mL}$ of dry DMF in a round bottom flask that was equipped with calcium chloride tube and cooled to $0{ }^{\circ} \mathrm{C}$. Then $3 \mathrm{~mL}$ of aniline $(32.88 \mathrm{mmol})$ were added gradually with continuous stirring and cooling. The mixture was then kept stirred at room temperature for 24 hours. The mixture was then acidified with $5 \mathrm{~N}$ hydrochloric acid, diluted to about $300 \mathrm{~mL}$ with cold water, and the precipitate formed was then filtered. The precipitate was washed with water $(3 \times 50 \mathrm{~mL})$. Then it was suspended in no more than $50 \mathrm{~mL}$ of icecooled water and the $\mathrm{pH}$ of this mixture was raised to 7 by a drop wise addition of $0.5 \mathrm{~N}$ sodium hydroxide solution at $0{ }^{\circ} \mathrm{C}$. The mixture was stirred for 30 minutes at $0{ }^{\circ} \mathrm{C}$ while maintaining this $\mathrm{pH}$ by addition of $0.5 \mathrm{~N}$ sodium hydroxide solution as needed. Then the mixture was filtered and the filtrate was evaporated to dryness.

Compound 6d: off-white powder, yield $35 \%$ relative to 6a, m. p. $259.5-263.8{ }^{\circ} \mathrm{C}$. FT-IR (ATR; v, $\mathrm{cm}^{-1}$ ): 3332 (aromatic NH), 3062 (aromatic C-H), 2939 (asym $\mathrm{CH}_{2}$ ), 2866 (sym. $\mathrm{CH}_{2}$ ), 1666 (amide $\mathrm{C}=\mathrm{O}$ ), 1600 (aromatic $\mathrm{C} \nRightarrow \mathrm{C} 1562($ asym carboxylate $\mathrm{C}=\mathrm{O})$,
1539 and 1500 (aromatic $\quad \mathrm{C}^{=} \mathrm{C}$ ), 1431 (sym. carboxylate $\mathrm{C}=\mathrm{O}$ ).

Compound 7d: off-white powder, yield $25.5 \%$ relative to $7 \mathbf{a}, \mathrm{m}$. p. $214-217^{\circ} \mathrm{C}$. FT-IR (ATR; v, $\mathrm{cm}^{-}$ $\left.{ }^{1}\right)$ : 3290 (aromatic NH), 3078 (aromatic C-H), 2920 (asym. $\mathrm{CH}_{2}$ ), 2858 (sym. $\mathrm{CH}_{2}$ ), 1654 (amide $\mathrm{C}=\mathrm{O}$ ), 1597 (aromatic $\mathrm{C}=\mathrm{C}$ ), 1558 (asym. carboxylate $\mathrm{C}=\mathrm{O}$ ), 1543 and 1496 (aromatic $\mathrm{C}=\mathrm{C}$ ), 1435 (sym. carboxylate $\mathrm{C}=\mathrm{O}$ ).

General synthesis of adipic monoanilide acid chloride and pimelic monoanilide acid chloride (6e and 7e)

Compound $\mathbf{6 d}$ or $\mathbf{7 d}$ ( $4 \mathrm{mmol})$ was suspended in $15 \mathrm{~mL}$ dry dichloromethane in a round bottom flask that was equipped with calcium chloride tube and cooled in an ice bath. Pyridine ( $4 \mathrm{mmol}, 0.32$ $\mathrm{mL}$ ) was added followed by a drop wise addition of $0.34 \mathrm{~mL}$ of thionyl chloride $(4.8 \mathrm{mmol})$ with continuous stirring and cooling for 10 minutes. The mixture was then allowed to warm to room temperature with continuous stirring for 30 minutes. Then the precipitate formed was collected using Büchner funnel. The precipitate was washed with dry dichloromethane $(3 \times 10 \mathrm{~mL})$ during filtration. The white solid mass obtained (in both cases of $\mathbf{6 e}$ and 7e) was used as such in the next step.

Compound 6e FT-IR (ATR; v, $\mathrm{cm}^{-1}$ ): 3313 (aromatic $\mathrm{NH}), 3066$ (aromatic C-H), 2935 (asym. $\mathrm{CH}_{2}$ ), 2870 (sym. $\mathrm{CH}_{2}$ ), 1797 (acid chloride $\mathrm{C}=\mathrm{O}$ ), 1662 (amide $\mathrm{C}=\mathrm{O}$ ), 1600, 1535 and 1500 (aromatic $\mathrm{C}=\mathrm{C}$ ).

Compound 7e FT-IR (ATR; v, $\mathrm{cm}^{-1}$ ): 3313 (aromatic $\mathrm{NH}$ ), 3043 (aromatic C-H), 2939 (asym. $\mathrm{CH}_{2}$ ), 2870

(sym. $\mathrm{CH}_{2}$ ), 1797 (acid chloride $\mathrm{C}=\mathrm{O}$ ), 1662 (amide $\mathrm{C}=\mathrm{O}$ ), 1597, 1527 and 1500 (aromatic $\mathrm{C}=\mathrm{C}$ ).

General synthesis of adipic monoanilide amide and pimelic monoanilide amide (6 and 7)

The precipitate obtained from the previous step (6e or 7e) was suspended in $10 \mathrm{~mL}$ of anhydrous cold acetone and added gradually to $10 \mathrm{~mL}$ of concentrated aqueous ammonium hydroxide solution that was cooled in an ice bath. The mixture was stirred for 30 minutes while maintained in the ice bath, then extracted three times with $5 \mathrm{~mL}$ portions dichloromethane. The organic phase was evaporated to dryness under reduced pressure.

Compound 6: white powder, yield $65 \%$ (relative to 6d), m. p. $\quad 178.2-\quad 179.3 \quad{ }^{\circ} \mathrm{C}, \quad \mathrm{R}_{\mathrm{f}} \quad 0.34$ (dichloromethane: 1-propanol; 8:2). FT-IR (ATR; v, $\mathrm{cm}^{-1}$ ): 3390 (asym. aliphatic NH) 3305 (aromatic NH), 3194 (sym. aliphatic NH), 3043 (aromatic CH), 2951 (asym. $\mathrm{CH}_{2}$ ), 2873 (sym. $\mathrm{CH}_{2}$ ), 1643 (br, aliphatic and aromatic amide $\mathrm{C}=\mathrm{O}), 1597,1523$ and 1500 (aromatic $\mathrm{C}^{=}=\mathrm{C} \quad$ ).

${ }^{1} \mathrm{H}-\mathrm{NMR}(\delta, \mathrm{ppm}): 1.54\left(\mathrm{~m},-\mathrm{CH}_{2}-\mathrm{CH}_{2-}, 4 \mathrm{H}\right), 2.07$ $\left(\mathrm{t}\right.$, aliphatic $\left.-\mathrm{CH}_{2}-\mathrm{C}(\mathrm{O})-, 2 \mathrm{H}\right), 2.29(\mathrm{t}$, aromatic $\left.\mathrm{CH}_{2}-\mathrm{C}(\mathrm{O})-, 2 \mathrm{H}\right), 6.71$ (br, $\left.-\mathrm{NH}_{2}, 1 \mathrm{H}\right), 7.02$ (t, $p$-CH, $1 \mathrm{H}), 7.28\left(\mathrm{t}, m-\mathrm{CH}, 2 \mathrm{H}\right.$; and $\left.-\mathrm{NH}_{2}, 1 \mathrm{H}\right), 7.58(\mathrm{~d}, o-$ $\mathrm{CH}, 2 \mathrm{H}), 9.86$ (s, -NH-1H). 
${ }^{13}$ C-NMR $(\delta): ~ 24.78,24.87,34.90,36.23,119.03$, 122.94, 128.60, 139.24, 171.15, 174.26.

Compound 7: gray crystals, yield $55 \%$ (relative to 7d), m. p. $127-129^{\circ} \mathrm{C}, \mathrm{R}_{\mathrm{f}} 0.42$ (dichloromethane: 1propanol; 8:2). FT-IR (ATR; v, $\mathrm{cm}^{-1}$ ): 3367 (asym. aliphatic NH) 3313 (aromatic NH), 3174 (sym. aliphatic NH), 3043 (aromatic C-H), 2939 (asym. $\mathrm{CH}_{2}$ ), 2854 (sym. $\mathrm{CH}_{2}$ ), 1658 (br, aliphatic and aromatic amide $\mathrm{C}=\mathrm{O}$ ), 1597, 1523 and 1496 ( aromatic $\mathrm{C}=\mathrm{C}$ ).

${ }^{1} \mathrm{H}-\mathrm{NMR}(\delta): 1.28\left(\mathrm{t},-\mathrm{CH}_{2}-2 \mathrm{H}\right), 1.54\left(\mathrm{~m},-\mathrm{CH}_{2-}\right.$ $\left.\mathrm{CH}_{2^{-}}, 4 \mathrm{H}\right), 2.04$ (t, aliphatic $\left.-\mathrm{CH}_{2}-\mathrm{C}(\mathrm{O})-, 2 \mathrm{H}\right), 2.29$ (t, aromatic $\left.-\mathrm{CH}_{2}-\mathrm{C}(\mathrm{O})-, 2 \mathrm{H}\right), 6.68\left(\mathrm{br},-\mathrm{NH}_{2}, 1 \mathrm{H}\right)$, 7.01 (t, $p-\mathrm{CH}, 1 \mathrm{H}), 7.28$ (t, $m-\mathrm{CH}, 2 \mathrm{H}$; and $-\mathrm{NH}_{2}$, $1 \mathrm{H}), 7.58(\mathrm{~d}, o-\mathrm{CH}, 2 \mathrm{H}), 9.85(\mathrm{~s},-\mathrm{NH}-1 \mathrm{H})$.

${ }^{13}$ C-NMR $(\delta): 24.85,24.89,28.31,34.94,36.27$, 119.02, 122.92, 128.60, 139.25, 171.24, 174.37.

Maintenance of cell cultures

HRT-18, HC-04, and HBL-100 (epithelial cells obtained from healthy human breast milk) cell lines were maintained in RPMI-1640 medium with which $10 \%$ fetal bovine was supplemented, 100 units/mL penicillin, and $100 \mu \mathrm{g} / \mathrm{mL}$ streptomycin. The cells were subcultured using Trypsin-EDTA, reseeded, once getting $80 \%$ confluence, two times a week, and incubated at $37^{\circ} \mathrm{C}{ }^{(17)}$.

\section{Cytotoxicity assay}

MTT cell viability assay was done using 96-well plates. The chosen cell lines were seeded at $1 \times 10^{4}$ cells/well. After either 24 hours or a confluent monolayer had been obtained, the cells were treated with compounds 6 or 7 at different concentration $(6.25,12.5,25,50,100 \mu \mathrm{M})$. After a 72 hours- treatment period, the cell viability was measured by removing the medium, adding $28 \mu \mathrm{L}$ of $2 \mathrm{mg} / \mathrm{mL}$ solution of MTT stain and incubating the cells for 2.5 hours at $37{ }^{\circ} \mathrm{C}$. Then the MTT solution was removed and the remaining crystals in the wells were dissolved in $130 \mu \mathrm{L}$ of dimethyl sulfoxide followed by $37{ }^{\circ} \mathrm{C}$ incubation for 15 minutes with shaking (18)]. The absorbency was determined on a microplate reader at $492 \mathrm{~nm}$; the assay was performed in triplicate.

The inhibition rate of cell growth (the percentage of cytotoxicity) was calculated according to the following equation:

$$
\text { Cytotoxicity }(\%)=\frac{A-B}{A} \times 100
$$

where A is the optical density of the control and B is the optical density of the sample.

The morphology of cells was visualized by the aid of inverted microscope. $200 \mu \mathrm{L}$ of cell suspensions were seeded in 96-well micro-titration plates at density $1 \times 10^{4}$ cells/ $\mathrm{mL}$ and incubated for 48 hours at $37{ }^{\circ} \mathrm{C}$. After removing the medium, compound 6 or 7 was added at the $\left(\mathrm{IC}_{50}\right)$. Then, after the exposure time, $50 \mu \mathrm{L}$ of crystal violet were used to stain the plates which were incubated at 37 ${ }^{\circ} \mathrm{C}$ for $15 \mathrm{~min}$; gentle washing of the stain was done with water until no more dye remained. A 40x magnification of inverted microscope was selected to examine the cells; they were photographed with a digital camera.

\section{Statistical analysis}

Unpaired t-test (using GraphPad Prism 6) was applied for the statistical analysis of the collected data. The values were presented as the mean \pm SEM of triplicate measurements.

\section{Results and discussion \\ Chemical synthesis}

Synthesis of the target compounds (6 and 7) was started from adipic acid (6a) and pimelic acid (7a) respectively (Scheme 1). Heating these dicarboxylic acids in acetic anhydride for 1 hour would result in monomeric cyclic anhydrides $(\mathbf{6 b}$ and 7b). However, these anhydrides are extremely unstable and some of the synthesized amount is converted into polymeric anhydrides (6c and 7c) rapidly during evaporation of the solvent ${ }^{(11,19)}$. The anhydride mixture (6b and $\mathbf{6 c}$, or $\mathbf{7 b}$ and $\mathbf{7 c}$ ) was used as such in the next step which is a modified procedure from previously published works ${ }^{(20,21)}$. In this step, a slight excess of aniline (1.2 eq. relative to $\mathbf{6} \mathbf{a}$ and $7 \mathbf{a}$ ) was added gradually to an ice-cooled solution of the anhydride mixture (in dry DMF) and, then, stirred at room temperature for 24 hours. The sodium salts (6d and 7d) were obtained by treatment of the precipitate, resulted after cold acidification of the reaction mixture and filtration, with gradually increasing amounts of ice-cooled $\mathrm{NaOH}$ solution $(0.5 \mathrm{~N})$ so that the $\mathrm{pH}$ was not raised above 7 . After filtration and evaporation to dryness, the off-white precipitate (6d and 7d) showed the characteristic FT-IR amide peaks (respectively) at $3332 \mathrm{~cm}^{-1}$ and $3290 \mathrm{~cm}^{-1}$ (aromatic $\mathrm{NH}$ ) and at $1666 \mathrm{~cm}^{-1}$ and $1654 \mathrm{~cm}^{-1}$ (amide carbonyl). Furthermore, the carboxylate peaks were at $1562 \mathrm{~cm}^{-1}$ (asym. C=O) and $1431 \mathrm{~cm}^{-1}$ (sym. C=O) for $\mathbf{6 d}$ and at $1558 \mathrm{~cm}^{-1}$ (asym. $\mathrm{C}=\mathrm{O}$ ) and $1435 \mathrm{~cm}^{-1}$ (sym. $\mathrm{C}=\mathrm{O}$ ) for $\mathbf{7 d}$. These anilides were prepared as sodium salts in order to keep the amide function stable during the next step which involved the synthesis of the acid chlorides 6e and 7e using thionyl chloride in the presence of 1 equivalent of pyridine ${ }^{(22)}$, thus avoiding the liberation of $\mathrm{HCl}$. Both $6 \mathbf{e}$ and $7 \mathbf{e}$ showed a new characteristic FT-IR carbonyl peak (of acid chloride) at $1797 \mathrm{~cm}^{-1}$ with the disappearance of all of the carboxylate peaks. 
<smiles>[Y]CC(=O)OC(=O)CC(C)(C)CC(=O)OC(C)(CC(=O)CC(C)(C)CC(C)(C)CC(=O)O)CC(=O)OC(=O)CC(C)(C)CC(=O)O</smiles>

$6 \mathbf{b}$

$7 \mathbf{b}$ 6c
$6 b, 7 b, 6 c, 7 c \stackrel{\begin{array}{c}1 . \mathrm{C}_{6} \mathrm{H}_{5} \mathrm{NH}_{2} / \mathrm{DMF} \\ \stackrel{25{ }^{\circ} \mathrm{C}, 24 \mathrm{~h}}{2.0 .5 \mathrm{NaOH}}\end{array}}{2.5 \mathrm{NaO}}$<smiles>CCCC(C)(C)CC(=O)Nc1ccccc1</smiles>

6d, 7d

6d, 7d

\section{1. $\mathrm{C}_{5} \mathrm{H}_{5} \mathrm{~N} / \mathrm{DCM}$}

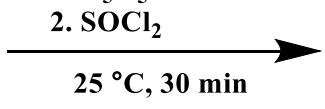

$6 e, 7 e$

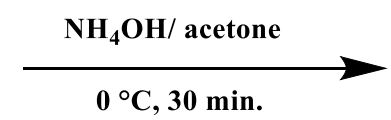

6,7

\section{Scheme 1. Synthesis of the target compounds (6 and 7)}

The final step of synthesis involved primary amide formation ( 6 and 7 ) by modifying a simple procedure using ice-cooled concentrated aqueous ammonia solution ${ }^{[23]}$. The FT-IR spectrum showed the disappearance of the $1797 \mathrm{~cm}^{-1}$ peak for both 6 and 7 while the amide carbonyl peaks (1643 $\mathrm{cm}^{-1}$ and $1658 \mathrm{~cm}^{-1}$, respectively) became broad because of the overlap of the primary and secondary amide carbonyl groups.

The two protons attached to the nitrogen of the primary amide are chemically not equivalent due to hindered amine rotation (24). This is illustrated by the difference in their chemical shifts in the ${ }^{1} \mathrm{H}-\mathrm{NMR}$ spectrum of 6 and 7 (0.57 ppm and $0.6 \mathrm{ppm}$ respectively).

\section{Cytotoxicity study}

Compounds 6 and 7 were tested in vitro for antiproliferative activity against HRT-18 cell line (human colon adenocarcinoma), HC-04 cell line (mouse hepatic carcinoma), and HBL-100 cell line ( epithelial cells obtained from healthy human breast milk) at micromolar concentrations $(6.25,12.5,25$, $50,100 \mu \mathrm{M})$. Both of them showed inhibitory activity against the cancer cell lines higher than against the normal cell line. Figures 3 and 4 show that there is a continuous and parallel increase in the inhibition of growth of both compounds against both colon adenocarcinoma and hepatic carcinoma with increasing the concentration. On the other hand, they show very low cytotoxicity against normal cells. 

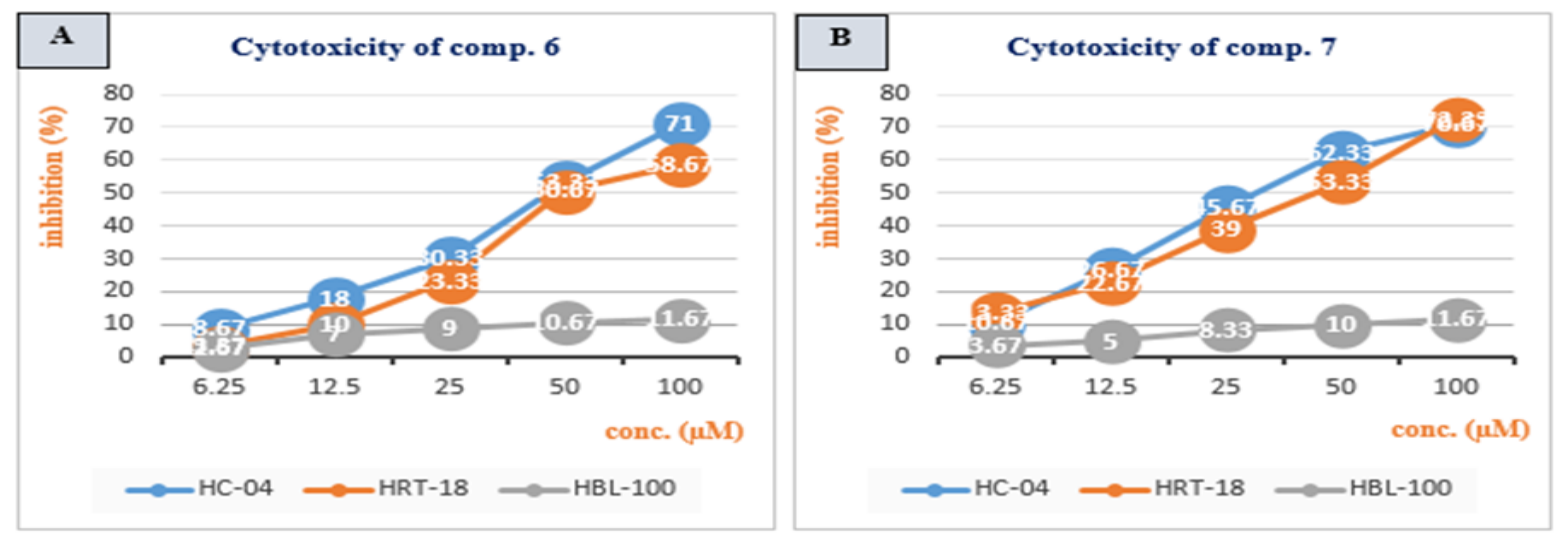

Figure 3. Concentration-growth inhibition curve of the tested compounds against hepatic carcinoma cells (blue), colon adenocarcinoma (orange) and healthy breast cells (gray). (A): the cytotoxicity of compound 6. (B): the cytotoxicity of compound 7
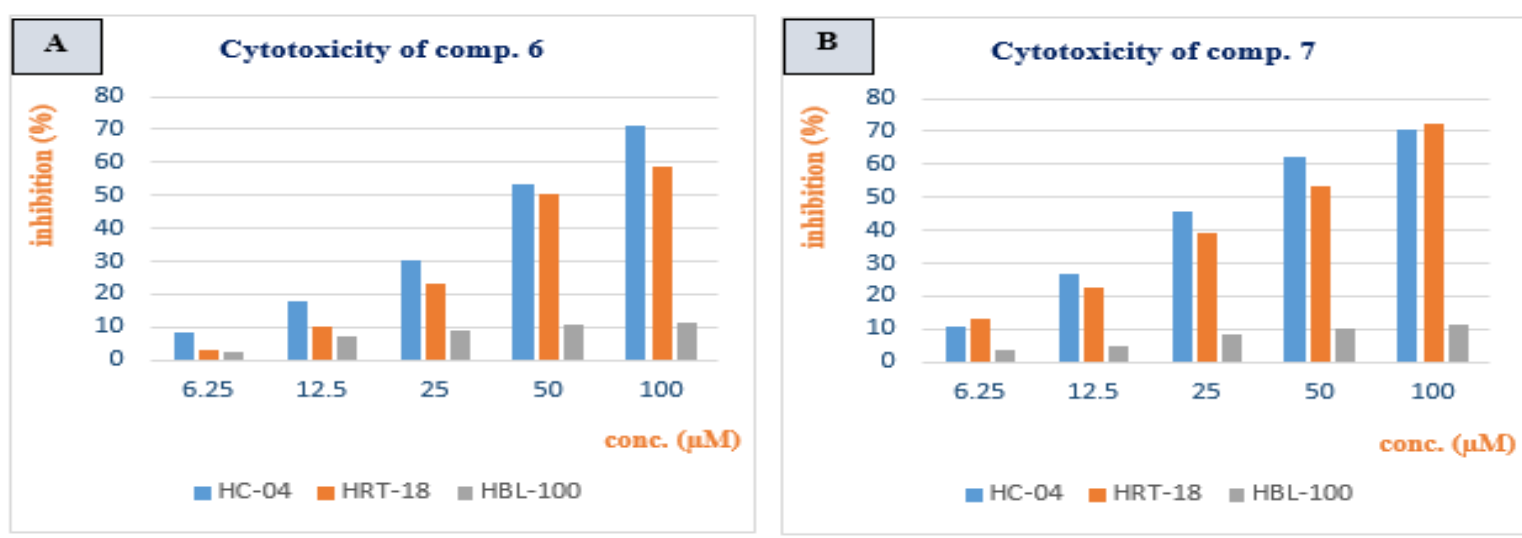

Figure 4. Histogram showing the concentration and growth inhibition of the tested compounds against hepatic carcinoma cells (blue), colon adenocarcinoma (orange) and healthy breast cells (gray). (A): the cytotoxicity of compound 6 . (B): the cytotoxicity of compound 7

Compound 7 shows higher cytotoxicity than compound 6 against the tested cancer cells ( Figure 5). Its $\mathrm{IC}_{50}$ against HC-04 cell line and HRT-18 cell line are $29.43 \mu \mathrm{M}$ and $33.92 \mu \mathrm{M}$ respectively while those for compound 6 are $45.83 \mu \mathrm{M}$ and $47.93 \mu \mathrm{M}$. Figure 6 (captured at the $\mathrm{IC}_{50}$ ) shows the difference in the magnitude of cytotoxicity between the two compounds.
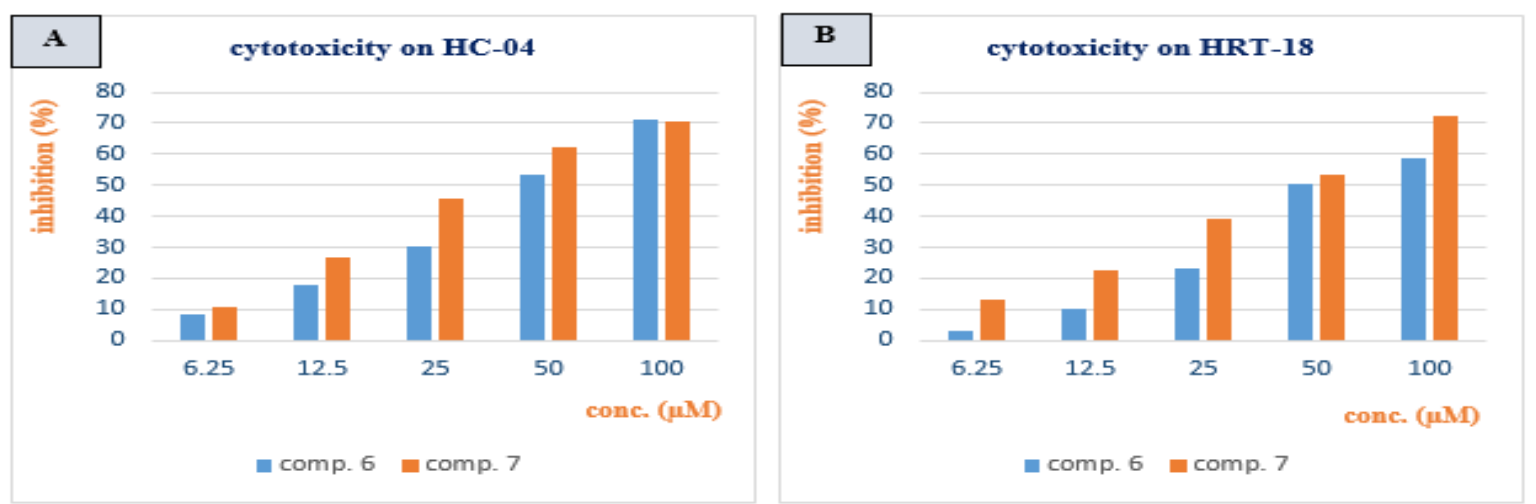

Figure 5. Histogram showing the concentration and growth inhibition of the compounds 6 and 7, (A): against hepatic carcinoma cells and $(B)$ : against colon adenocarcinoma 


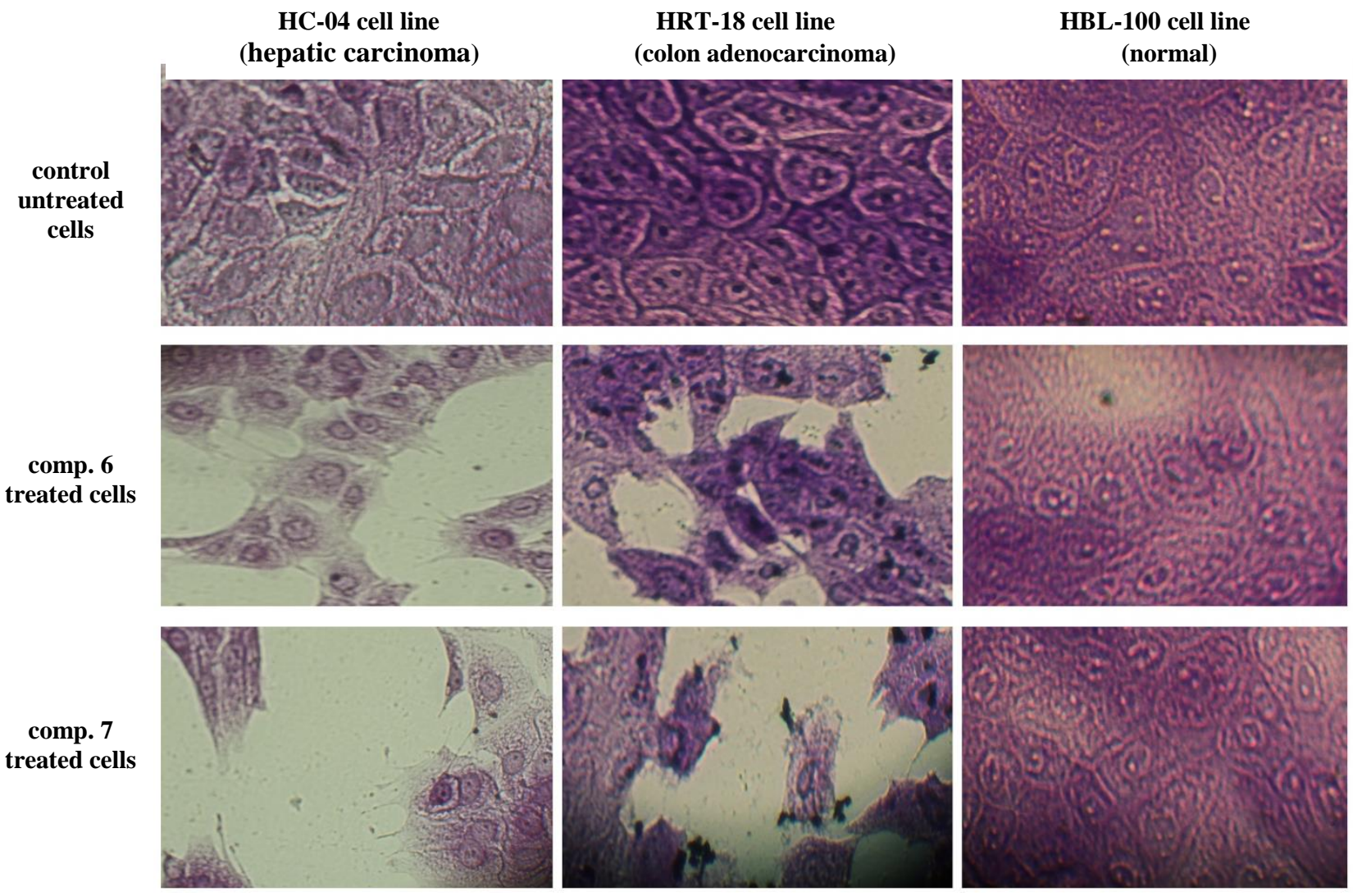

Figure 6. Morphology of the cell lines after treatment with compounds 6 and 7 at the IC $_{50}$ (40x magnified)

The low cytotoxicity of both compounds against normal cells gives hope of being able to target cancer cells to a higher degree than normal cells. No more than $12 \%$ of inhibition of growth was observed at the highest concentration used for both compounds (Figure 7). This might possibly be

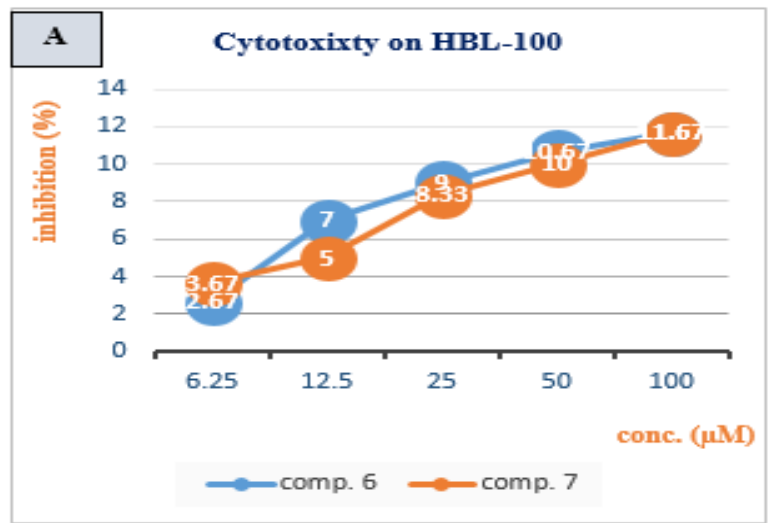

considered, in agreement with previous reports, that the synthesized compounds might exhibit relative specificity in inhibiting HDACs that are overexpressed in cancer cells.

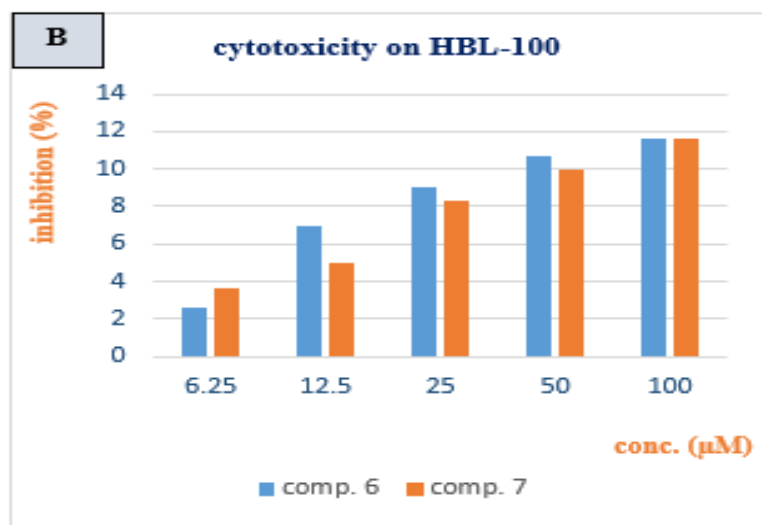

Figure 7. Low cytotoxicity of compounds 6 and 7 on normal breast cells. (A): Concentration-growth inhibition curve. (B): Histogram showing the concentration and growth inhibition

\section{Conclusion}

Synthesis of the target primary amides (6 and 7) was achieved starting from adipic acid (6a) and pimelic acid (7a) respectively. They were fully characterized successfully. Both of them showed good cytotoxicity against cancer cell lines
(HC-04 and HRT-18) and lower cytotoxicity against normal cell line (HBL-100).

\section{References}

1. Delcuve GP, Khan DH, Davie JR. Targeting class I histone deacetylases in cancer therapy. Expert Opin Ther Targets. 2012;17(1):29-41. 
2. Burtis CA, Ashwood ER, Bruns DE. Tietz Textbook of Clinical Chemistry and Molecular Diagnostics. Fifth. Missouri: ELSEVIER; 2012. 1212-1214 p.

3. Manal M, Chandrasekar MJN, Gomathi Priya J, Nanjan MJ. Inhibitors of histone deacetylase as antitumor agents: A critical review. Bioorg Chem. 2016;67:18-42.

4. RUIJTER AJM de, GENNIP AH van, CARON HN, KEMP S, KUILENBURG ABP van. Histone deacetylases (HDACs): characterization of the classical HDAC family. Biochem J. 2003;370(3):737-49.

5. Zhang L, Zhang J, Jiang Q, Zhang L, Song W. Zinc binding groups for histone deacetylase inhibitors. J Enzyme Inhib Med Chem. 2018;33(1):714-21.

6. Traoré MDM, Zwick V, SimoÌes-Pires CA, Nurisso A, Issa M, Cuendet M, et al. Hydroxyl Ketone-Based Histone Deacetylase Inhibitors to Gain Insight into Class i HDAC Selectivity versus That of HDAC6. ACS Omega. 2017;2(4):1550-62.

7. Kim H-J, Bae S-C. Histone deacetylase inhibitors: molecular mechanisms of action and clinical trials as anti-cancer drugs. Am J Transl Res. 2011;3(2):166-79.

8. Lauffer BEL, Mintzer R, Fong R, Mukund S, Tam C, Zilberleyb I, et al. Histone deacetylase (HDAC) inhibitor kinetic rate constants correlate with cellular histone acetylation but not transcription and cell viability. J Biol Chem. 2013;288(37):26926-43.

9. Wang DF, Helquist P, Wiech NL, Wiest O. Toward selective histone deacetylase inhibitor design: Homology modeling, docking studies, and molecular dynamics simulations of human class I histone deacetylases. J Med Chem. 2005;48(22):6936-47.

10. Marks PA. Discovery and development of SAHA as an anticancer agent. Oncogene. 2007;26(9):1351-6.

11. Herman D, Jenssen K, Burnett R, Soragni E, Perlman SL, Gottesfeld JM. Histone deacetylase inhibitors reverse gene silencing in Friedreich's ataxia. Nat Chem Biol. 2006;2(10):551-8.

12. Beconi M, Aziz O, Matthews $K$, Moumné L, O'Connell C, Yates D, et al. Oral Administration of the Pimelic Diphenylamide HDAC Inhibitor HDACi 4b Is Unsuitable for Chronic Inhibition of HDAC Activity in the CNS In Vivo. PLoS One. 2012;7(9).

13. Attenni B, Ontoria JM, Cruz JC, Rowley M, Schultz-Fademrecht C, Steinkühler C, et al. Histone deacetylase inhibitors with a primary amide zinc binding group display antitumor activity in xenograft model. Bioorg Med Chem Lett. 2009;19(11):3081-4.

14. Pettersen EF, Goddard TD, Huang CC, Couch GS, Greenblatt DM, Meng EC, et al. UCSF Chimera-a visualization system for exploratory research and analysis. J Comput Chem. 2004;25(13):1605-12.

15. Berman HM, Westbrook J, Feng Z, Gilliland G, Bhat TN, Weissig H, et al. The Protein Data Bank www.rcsb.org. Nucleic Acids Res. 2000;28(1):235-42.

16. Bressi JC, Jennings AJ, Skene R, Wu Y, Melkus $\mathrm{R}$, Jong R De, et al. Exploration of the HDAC2 foot pocket: Synthesis and SAR of substituted N-(2-aminophenyl)benzamides. Bioorg Med Chem Lett. 2010;20(10):3142-5.

17. Sulaiman GM, Jabir MS, Hameed AH. Nanoscale modification of chrysin for improved of therapeutic efficiency and cytotoxicity. Artif Cells, Nanomedicine Biotechnol. 2018;46(sup1):708-20.

18. Jabir MS, Taha AA, Sahib UI, Taqi ZJ, AlShammari AM, Salman AS. Novel of nano delivery system for Linalool loaded on gold nanoparticles conjugated with CALNN peptide for application in drug uptake and induction of cell death on breast cancer cell line. Mater Sci Eng C. 2019;94(March 2018):949-64.

19. Julian W. Hill. Studies On Polymerization And Ring Formation. VI. Adipic Anhydride. J Am Chem Soc. 1930;52:4110-4.

20. Letton JC, Miller LE. Process for the preparation of mono-condensation derivatives of adipic acid. US5286879A, 1994.

21. Stowell JC, Huot RI, Van Voast L. The Synthesis of N-Hydroxy-N'phenyloctanediamide and Its Inhibitory Effect on Proliferation of AXC Rat Prostate Cancer Cells. J Med Chem. 1995;38(8):1411-3.

22. Wolfe S, Godfrey JC, Holdrege CT, Perron YG. Rearrangement of penicillins to anhydropenicillins. Can J Chem. 1968;46(15):2549-59.

23. Roe ET, Scanlan JT, Swern D. Fatty Acid Amides. I. Preparation of Amides of Oleic and the 9, 10-Dihydroxystearic Acids. J Am Chem Soc. 1949;71(6):2215-8.

24. Gorobets NY, Yermolayev SA, Gurley T, Gurinov AA, Tolstoy PM, Shenderovich IG, et al. Difference between $1 \mathrm{H}$ NMR signals of primary amide protons as a simple spectral index of the amide intramolecular hydrogen bond strength. J Phys Org Chem. 2012;25:28795.

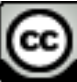

Baghdad Iraqi Journal Pharmaceutical Sciences by bijps is licensed under a Creative Commons Attribution 4.0 International License. Copyrights@ 2015 College of Pharmacy - University of Baghdad. 